\title{
ARTICLE
}

\section{The beginning of the end of prohibition: the politics of drug addiction}

\author{
Jason Luty
}

\begin{abstract}
Jason Luty is a consultant in addictions psychiatry at Borders Health in Scotland. He trained at the Maudsley Hospital, London, and spent 8 years as a consultant in addictions at the South Essex Partnership University NHS Foundation Trust, England. He has a $\mathrm{PhD}$ in pharmacology following a study of the molecular mechanisms of receptor desensitisation and tolerance and has published in the addictions field. Correspondence Dr Jason Luty, Borders Addiction Service, The Range, Tweed Road, Galashiels TD1 3EB, Scotland. Email: jason.luty@ yahoo.co.uk
\end{abstract}

\begin{abstract}
SUMMARY
Misuse of drugs such as opium, cocaine and cannabis was common around the world before the First World War and it provided a valuable market for the colonial powers. There seems to have been a brief period of sobriety between the two World Wars, along with widespread criminalisation of drug dealing and use, followed by an explosion of the illicit drug market and the hugely expensive US-led 'war on drugs'. The cost and impracticality of drug criminalisation, together with changes in Western public opinion, mean that cannabis legalisation has very recently been accepted in some countries and drug prohibition is being dismantled.
\end{abstract}

\section{LEARNING OBJECTIVES}

- Recognise that public opinion and political pressures both created, and now oppose, drug prohibition

- Recognise that drug policy is determined primarily by public opinion rather than scientific evidence, especially that legal drugs (tobacco and alcohol) are much greater public health problems than illicit drugs

- Understand that drug prohibition could not succeed without demand reduction as well as supply restriction

\section{DECLARATION OF INTEREST}

None

'A re-ordering of substances is indeed possible but the new positioning will be time dependent, the plaything of other issues, not a "rational" process' (Berridge 2013: p. 247).

In this article, I attempt to predict what will happen regarding the politics of addictive drugs - not what should happen. Prohibition and sobriety probably do not reflect the natural state of society, in which use of psychotropic drugs has been ritualised and socially sanctioned (whether alcohol in the West, opium in the Far East or cannabis in the Middle East).

Two trends can be observed, depending on local circumstances. First, there is a balance between criminalisation, control and legalisation. For example, 'control' includes regulation of pack size of paracetamol, the definition of quantities of cannabis an individual can posses for "personal use' and banning the selling of alcohol to children. Legislatures, including the European Union, regularly review regulation of herbal medicines, as well as newer 'legal highs'. (Indeed, this process is now becoming so onerous that it is often ineffective.)

Second, criminal gangs (like tobacco companies) are now diversifying their investment into other markets, although in the case of criminal syndicates of the former USSR and Balkans these tend to be other illicit trades, such as arms dealing, extortion and vice (Freudenberg 2014; LSE Ideas 2014).

\section{The prevalence and economics of drug misuse}

The United Nations Office on Drugs and Crime (UNODC 2013) estimated that globally in 2011 between 167 and 315 million adults used illicit substances and this was problematic in around 10\% (16-29 million people). It further estimated that around 14 million people worldwide were injecting drugs $(0.3 \%$ of the adult population), around 1.6 million of whom (11\%) were infected with HIV and 7 million (51\%) with hepatitis C. Global consumption of heroin is estimated at 340 tons (UNODC 2010), while in 2007 around 15 to 21 million people were using opiates recreationally, including 1.3 million in North America and 3.4-4 million in Europe (UNODC 2009). Perhaps onefifth of opioid-dependent people receive opioid maintenance treatment in the USA and Europe (European Monitoring Centre for Drugs and Drug Addiction 2009). Around 16-17 million people use cocaine regularly $-40 \%$ in the USA. About $80 \%$ of the global cocaine market of US $\$ 88$ billion is in the USA and Europe. The United Nations estimated that cannabis is used by around $4 \%$ of the adult world population; in 2004 perhaps 1 in 8 were using the drug daily, half of whom were 'dependent' on it (UNODC 2010; LSE Ideas 2014). 
The wealthiest countries consume the majority of illicit drugs as they can support the highest prices (5\% of the US population consume $68 \%$ of the global opium production) (LSE Ideas 2014). Most users do not become dependent - that is, they do not use on a daily basis or develop severe withdrawal symptoms. However, dependent drug users account for a disproportionate share of drug consumption. For example, surveys suggest that $83 \%$ of the heroin consumed in the USA in 2011 was taken by opiatedependent people (LSE Ideas 2014).

The global drug trade is worth around US $\$ 321$ billion - almost $1 \%$ of the world gross domestic product (GDP). This trade is so great that the Director of the UN Office on Drugs and Crime suggested that income from the drug trade was the principal factor that prevented the collapse of the world banking system in 2008 (LSE Ideas 2014).

The illicit drug market in the UK is estimated at $£ 5$ billion, with an estimated cost to society of $£ 13$ billion, or about 1\% of GDP (Reuter 2007). (By comparison, UK households spend around $£ 15$ billion a year on alcohol.) About $£ 9.7$ billion of this cost is estimated to be incurred by victims of such crime and over $£ 4$ billion is spent by the criminal justice system in dealing with these offenders. The UK Home Office estimates that drugs are the reason for $86 \%$ of shoplifting, $70-80 \%$ of burglaries and half of all robberies in the UK (Pudney 2003). In $2004,6 \%$ of arrests and $13 \%$ of convictions were for drugs offences, although $71 \%$ of all drugs offences were related to cannabis (most dealt with by cautions) (LSE Ideas 2014; Drug Policy Alliance 2015).

\section{The arbitrary nature of drug prohibition - alcohol and tobacco}

Prohibition of cannabis and other drugs is irrational in that, compared with them, alcohol causes overwhelming damage to wider society and the proportion of deaths from smoking-related disease continues to increase worldwide. For example, in the USA in 2000, smoking was the leading cause of preventable deaths (435000 deaths), with alcohol in third place (85000 deaths) and drug misuse tenth (17000 deaths) (Mokdad 2004), and smoking retains this lead today. Worldwide, smoking is the second leading risk factor for the total burden of disease, alcohol is third and drug misuse is 19 th (Lim 2012).

Prohibition of alcohol has been tried (unsuccessfully) in the past, and restrictions on sales of alcohol and tobacco are now vigorously opposed by the financial might of the industry. For example, globally the cigarette industry spent US $\$ 8.37$ billion on advertising in 2011. In 2013, the US state and national governments collected US $\$ 25.7$ billion from tobacco taxes. Despite the fact that cigarette smoking causes 1 in 5 deaths, US spending on smoking cessation treatment amounted to only $1.8 \%$ of the earnings from tobacco taxation. Furthermore, in 2000-2004, cigarette smoking was estimated to cost the USA $\$ 193$ billion ( $\$ 97$ billion in lost productivity plus $\$ 96$ billion in healthcare expenditures) (LSE Ideas 2014).

Alcohol misuse has been estimated to cost the UK up to $£ 6$ billion a year in healthcare costs, premature death, losses to business and drink-related crimes and accidents (Cabinet Office Strategy Unit 2013). A report from the Royal College of Physicians (2001) estimated that treating alcohol misuse costs the National Health Service (NHS) between 2 and $12 \%$ of its total hospital expenditure. This compares with the roughly $£ 15$ billion a year that households spend on the purchase of alcohol (Stockwell 2013). In 2009-2010 the UK government received $£ 9$ billion from alcohol duties and the alcohol industry supports up to two million jobs in the UK (Stockwell 2013).

\section{Early 20th-century drug prohibition - the International Opium Convention}

Many efforts have been made throughout history to regulate and prohibit drugs of misuse (Boxes 1-3), not least by the Chinese emperors prior to the Opium Wars ( 1839-1860). The first modern European law for the regulation of drugs was the UK Pharmacy Act 1868. In part this governed sales of opium, although it was relatively ineffective (Booth 1996; Berridge 2013). However, the gradual international expansion of the 'morally indefensible' opium and cocaine trade ultimately led to the USbacked Hague International Opium Convention in 1912, following concern about the spread of opium use from Chinese labourers in the Pacific states. The Convention required signatories to introduce gradual prohibition of opium and cocaine other than strictly for medical use. The aim was to eradicate the 'non-medical and non-scientific' use of drugs. It also prohibited opium dens, as well as 'the buildings in which these persons carry [sic] such an industry or trade' (Davenport-Hines 2002).

The Chinese Imperial Government attempted to ban opium farming in the first decade of the 20th century, although local administrations returned to opium as a source of revenue and to finance their political campaigns by the 1920s. Food crops were even replaced by opium in this period, leading to famines. After the First World War many European and foreign governments, including Britain, France and Japan, also ignored the treaties designed to eliminate opium trade. Hence the opium trade in 


\section{BOX 1 A brief history of opium}

People have grown opium poppies for drugs since the Stone Age - for at least 15000 years. Opium was used as a pain killer and in rituals by many ancient civilisations, including the Sumerians, Ancient Egyptians, Indians, Minoans, Persians, and the Greek and Roman Empires, as well as the Arab Empires who spread Islam and introduced opium to China around 1000 years ago. Opium was used recreationally in Muslim society and later in the Ottoman Empire at least 700 years ago

By the start of the 19th century, raw opium and laudanum (opium dissolved in alcohol) were widely available in pharmacies in England, Europe and the USA. Opium imports to Britain rose from 41 tonnes in 1830 to 125 tonnes in 1860 . Opium was used to treat pain, coughing, insomnia and diarrhoea, partly owing to the absence of other effective medications. In many cities a bottle of laudanum was cheaper than wine or gin, leading to widespread misuse of opium. For example, the wife of Abraham Lincoln was addicted to opium. Opium was used widely in the USA until its use was legally restricted to designated opium 'dens' in 1882

Western countries often supported the opium trade. For example, Britain defeated China in the First Opium War (1839-1842) and won the right for foreign powers to trade opium to the Chinese. Hence, most of the 41000 tonnes of opium produced in China in 1906 was consumed there perhaps one-quarter of the male population of China used opium recreationally. The former colonial powers, Britain and France, actively promoted and controlled the opium trade in the Far East, including French Indochina (Vietnam), until the 1950s.

(Latimer 1981; McCoy 1991; Chouvy 2009)

French intelligence and paramilitary agencies began to monopolise the opium trade in order to finance their covert operations during the First Indochina War as part of the resistance to Vietnamese independence (1946-1954) ('Operation X') (McCoy 1972). Similarly, Burma became independent at the end of the Second World War and opium cultivation began to flourish. In the 1950s, US efforts to contain the spread of Communism in Asia involved making alliances with warlords in Laos, Thailand and Burma (the 'Golden Triangle', where world opium production became concentrated). Representatives of the US and French intelligence services in South East Asia sold local warlords ammunition and weapons to finance Western military operations there. The warlords themselves purchased these weapons using income from the production and sale of opium. (Ironically, this opium was often sold to US troops serving in South East Asia.) This led to an epidemic of illicit heroin use in Western countries (McCoy 1991; Baumler 2001). The widespread misuse of opium by US soldiers in the Vietnam War led directly to the current US 'war on drugs' and related international policies (see below).

China escalated to reach a peak in 1930 (UNODC 2007). The opium trade was also used to finance the Chinese Communist Party in the 1940s, although Chairman Mao brutally suppressed the domestic opium trade in China in the 1950s (Booth 1996; Baumler 2001).

\section{The opium trade in Indochina}

The French colonial government's campaign to eliminate opium addiction in Indochina (now Vietnam, Laos and Cambodia) began in 1946 with the abolition of the opium monopoly. However,

\section{B0X 2 A brief history of cocaine}

Chewing the leaves of the coca plant to release cocaine alkaloids was done at least 3000 years ago by native labourers in the Andes. During the time of the Spanish occupation of South America, workers in the silver mines were given regular breaks to receive coca leaves. This habit spread to industrial workers in North America by 1900, where coca had become cheaper than alcohol. Cocaine was used by Shackleton and Scott during their Antarctic explorations. Cocaine was purified in 1859 and was used recreationally in a purified pharmaceutical preparation by such luminaries as Sigmund Freud, Jules Verne, Alexander Dumas, Sir Arthur Conan Doyle (and Sherlock Holmes).
It is alleged that cocaine was tried by Pope Leo XIII, Queen Victoria and Ulysses S. Grant and that Robert Lewis Stephenson wrote the novel Dr Jekyll and Mr Hyde while under the influence of cocaine.

Coca alkaloids were constituents of Coca Cola from 1886 until 1903, during which sales of the beverage spread internationally. Cocaine was also used widely by Hollywood film stars during the Roaring Twenties. Germany was one of the main manufacturers of pharmaceutical cocaine until the end of the Second World War.

(Gootenberg 1999; Karch 2005; Feiling 2009)

\section{The 1961 Single Convention on Narcotic Drugs and subsequent prohibition}

The period immediately after the Second World War was a time of social upheaval. In the UK, the 1950s saw the publication of government reports that recommended the legalisation of homosexuality, prostitution and abortion (the Wolfenden and Birkett Committee reports). However, drug addiction was not seen as a major social problem in the country at that time. Nevertheless, the United Nations gradually introduced international measures to strengthen prohibition, with the Single Convention on Narcotic Drugs in 1961, the Convention on Psychotropic Substances in 1971 and the Convention against Illicit Traffic in Narcotic Drugs and Psychotropic Substances in 1988.

The 1961 Convention led to the introduction of laws in Western countries criminalising the manufacture, possession and distribution of many addictive drugs other than for treatment of disease (as defined by doctors). The 1971 Convention was introduced to prohibit cannabis and synthetic drugs of misuse, which were not covered by the earlier treaties. It also introduced the current classification of drugs of misuse. The 1971 Convention allows reduction of jail sentences for people in treatment for drug problems. The 1988 Convention requires governments to cooperate to enforce prohibition, money laundering and extradition of drugs traffickers. It also allows an expert commission to add further synthetic substances, including 
BOX 3 A brief history of cannabis

For many decades cannabis (marijuana, hashish) has been the most widely used illegal drug. It has been used recreationally for 5000 years. Use of cannabis spread from China to India and then, with the expansion of Islam, to North Africa and Europe. In the late-16th century in America, cannabis was developed as a commercial crop, along with tobacco, by the British and Spanish. During his invasion of Egypt, Napoleon discovered that cannabis was used widely by Egyptian labourers and cannabis smoking became popular in France shortly afterwards Cannabis was widely sold and used recreationally in the USA between 1850 and 1915 prior to prohibition. Smoking cannabis remained common in the Middle East throughout much of the 20th century.

(Deitch 2003; Cervantes 2015)

precursors, to the list of narcotic drugs without amendment to the Convention. In late 2002, a European Parliament committee recommended repealing the 1988 Convention on the grounds that prohibition had proven to be ineffective despite huge costs spent on policing illicit drugs (Cappato 2002).

Regrettably, laws remain national whereas the drug trade is global and can easily be conducted in countries that are unwilling or unable to enforce prohibitionist laws. Paradoxically, the high prices of illicit drugs in wealthy countries that are produced by prohibition laws generate enormous revenues for drug traders, who are often based in poor countries. This money can be used to intimidate and corrupt entire governments (LSE Ideas 2014). It has been estimated that, in 2005 , the price of opium increased 500-fold during trading, from $£ 204$ for $4 \mathrm{~kg}$ of opium in Afghanistan to $£ 54000$ for $1 \mathrm{~kg}$ of heroin (its derivative) on Britain's streets (Reuter 2007). If it were legal, cocaine would probably cost as much to produce and distribute as coffee. For example, drug dealers demand around US $\$ 10000 /$ $\mathrm{kg}$ to move cocaine from South America to the USA; FedEx will ship a kilogram of any other package for around US\$60 (LSE Ideas 2014). This price escalation is almost entirely due to legal prohibition and compensation for risk-taking. It also means that there are enormous profits for those suppliers who successfully evade detection.

Evasion of national law enforcement also illustrates the great mobility of the illicit drug trade. For example, at the accession of communism opium production moved from China to the newly independent states of Laos, Thailand and Burma. At the end of the Vietnam conflict production again moved, this time to Afghanistan. Similarly, Columbia became the major staging post for cocaine transport to the USA following production in Peru and Bolivia. However, this has gradually moved to Mexico and Nigeria following high-profile US military support of Columbia drug enforcement (LSE Ideas 2014).

A large international diaspora, corrupt governments and reasonable transport links attract the global drug trade. Bolivia and Peru are the principal producers of cocaine, although it is subsequently processed and shipped from Columbia and Mexico, which are closer to the USA. Afghanistan has dominated world opium production for almost 20 years. Iran has consistently been a major trafficking route, being geographically closer to Europe and also politically unsympathetic to the USA. Similarly, heroin trafficking through Tajikistan developed after the break-up of the Soviet Union and the creation of a large Russian heroin market. Nigeria has become a major trans-shipment country for cocaine. Nigeria has been ruled by several corrupt governments since independence. It has a large diaspora (many Nigerians live overseas), a weak civil society, very low domestic wages and reasonable international transport links. It is relatively easy to buy protection for illegal transactions in Nigerian airports (due to corruption and a weak governmental tradition) (LSE Ideas 2014).

\section{Criticism of the 'war on drugs'}

The 'war on drugs' is a US military and political campaign popularised by President Nixon in 1971 and aiming to eradicate international trade in illicit drugs. (For interest, President Nixon appointed Elvis Presley as one of his advisors on drugs.) Although the campaign has progressed continually, a more extreme phase developed in the George Bush administration (1989-1993) involving military intervention against Columbian drug cartels. The most recent administration, led by President Obama (who took office in 2009), has indicated that it does not plan to change the existing drug enforcement policy, which has an annual spend estimated at US $\$ 51$ billion (Drug Policy Alliance 2015), although the term 'war on drugs' is no longer used.

The Drug Policy Alliance (2015) has estimated that, over four decades, the USA has spent over US $\$ 1$ trillion in its fight against drugs. Despite this, the prices of illicit heroin and cocaine fell by 75$80 \%$ between the 1980 s and 2011 , partly due to the ability of the illicit drug trade to relocate between countries and partly because the illicit earnings allow drug lords to control the governments of poor countries. The 'war on drugs' is generally regarded as an expensive failure (Reuter 2007; LSE Ideas 2014). 
In 1986, the US Department of Defense funded a 2-year study by the RAND Corporation into the use of the military in drug interdiction. It concluded that the use of the US armed forces to prevent drugs coming into the USA would have little or no effect on cocaine availability (Reuter 1988). This supported the conclusions of seven previous studies.

Over US $\$ 7$ billion are spent annually on arresting and prosecuting people in the USA for cannabis-related offences (Miron 2005). Nevertheless, a US government-funded survey reported that around $85 \%$ of teenage students find cannabis 'easy to obtain'. Furthermore, the prevalence of cannabis use has remained stable for at least two decades. Illicit drug prices in the West have consistently fallen over the past 30 years despite the 'war on drugs'. For example, black-market heroin prices fell from US $\$ 1896$ per gram at 11\% purity in 1981 to US $\$ 408$ per gram at 28\% purity in 2011. Cocaine prices fell from US $\$ 669.18$ per 2 grams at $40 \%$ purity to US $\$ 177.26$ at $42 \%$ purity over the same period (Office of National Drug Control Policy 2013). Prices have fallen by 75-80\% since the 1980s (Davenport-Hines 2002; Bewley-Taylor 2003).

In 2014, a report from the London School of Economics Expert Group on the Economics of Drug Policy (which included five Nobel prize winners) concluded that the 'war on drugs' strategy has produced enormous damage. This includes 'mass incarceration in the USA, highly repressive policies in Asia, vast corruption and political destabilisation in Afghanistan and West Africa, immense violence in Latin America [and] an HIV epidemic in Russia' (Quah 2014: p. 3). A 'drug-free world' is no longer a realistic goal.

Latin American governments are no longer prepared to tolerate the political and economic consequences of the 'war on drugs', especially as the total cost of enforcing the UN prohibitionist policies can only be defrayed by aid grants of US\$400-500 million per year. To give an example of the damage caused, as US military enforcement against cocaine lords in Columbia became more effective around 2001, production shifted to Mexico (the 'ballooning effect'). The total homicide rate in Mexico increased threefold within 4 years, from about 8 homicides per 100000 individuals in 2006 to more than 23 in 2010. Between 2006 and 2012 an intensive police campaign against Mexico's major drug-trafficking organisations resulted in over 60000 drug-related homicides and 1.5 million people displaced from their homes (LSE Ideas 2014).

The LSE report (Quah 2014) highlighted that small, poor countries such as Guinea-Bissau or
Ghana may have no police or military to enforce anti-smuggling laws, making them ideal bases for the processing of drugs. The same is true for politically unstable countries, especially Afghanistan, Iran and so-called 'narco-states' in East Africa and Central America. Regrettably, government officers involved in enforcing prohibition in poor countries are ideally placed to become the top traffickers because they are able to evade the existing smuggling laws. They are also vulnerable to bribery and intimidation by powerful drug lords, including the assassination and kidnapping of family members.

Even wealthy countries have found the "war on drugs' impractical (Quah 2014). The Dutch government found that their prisons and courts were unable to process the 1300 cocaine couriers arrested at Amsterdam airport during the course of 2001. Consequently, they introduced a policy of confiscating the drugs and the passport of the trafficker and banning their further international flights (through The Netherlands). The number of detected couriers fell to only 40 in 2005, at an immense saving to the Dutch judicial system.

It is unlikely that class A drugs (heroin and cocaine) will be legalised in the near future. However, in 2001, in a frequently misrepresented judgment, Portugal decriminalised possession of a small amount of any drug. Hence, possession of modest quantities of heroin are subject to noncriminal penalties such as diversion to treatment or educational programmes (Berridge 2013). Nonetheless, drug dealing remains criminal and it is the criminalisation of distribution (rather than possession) that leads to the highly inflated illicit prices (and profits) that drive acquisitive crime.

\section{Cannabis legalisation}

January 1969 saw the publication in the UK of a report on cannabis by the Advisory Committee on Drug Dependence. Named after the committee's chair, Baroness Wootton, the report on cannabis prohibition was remarkably liberal and referred to the socially damaging consequences of criminalising cannabis (Advisory Committee on Drug Dependence 1969). The Wootton Report came at the end of a period of liberal government and its recommendations were largely ignored by the subsequent austere and conservative regimes in the UK (and also in the USA) (Holden 2004).

Almost 50 years on, a new, more liberal regime appears to be developing. This may be due to the pragmatic fact that the 'war on drugs' has not worked - drug use has persisted and even increased despite hugely expensive police and military campaigns to eliminate the trade. Furthermore, public opinion, particularly in the USA, may have 
gradually become more tolerant of drug use. Since 1996, 20 US states have permitted cannabinoids to be used for approved medical purposes, although this does not include smoking cannabis in cigarettes (Farrell 2014). The medically sanctioned use of cannabinoids for treatment of multiple sclerosis in the 1990s is likely to have prepared the way for public acceptance of cannabis, with legalisation and decriminalisation in the West. Opinion polls in the USA now show public approval for legalising cannabis. One survey of 1800 US adults found that $54 \%$ thought the drug should be made legal (Pew Research Centre 2014). Around half of the survey respondents had tried cannabis and 70\% regarded cannabis as less harmful than alcohol. When Gallup surveyed the question in the USA in 1969, only $12 \%$ of respondents had favoured legalisation.

Traditionally restrictive administrations in the US have begun to adopt more lenient policies. In 2012, voters in two states, Colorado and Washington state, approved policies to legalise the sale and recreational use of marijuana by adults (UNODC 2013). The Colorado Amendment 64 of 6 November 2012 allowed the sale of modest quantities of cannabis to registered users from 1 January 2014. This followed a state referendum in which 55\% of people voted to legalise cannabis. A similar amendment was adopted by the Washington state government (Washington Initiative 502) following a referendum in which a similar proportion (almost $56 \%$ ) voted in favour of legalisation. These changes are taking place despite the fact that they contravene the 1961 and 1988 United Nations Conventions on drugs, and the US Attorney General has stated that they will not seek to enforce these Conventions.

In August 2013, Uruguay became the first country in modern times to legalise the production and sale of cannabis, although sale is only to registered consumers. Nevertheless, public support for the legalisation in Uruguay was low. According to 2012-2013 polls, 58-66\% of Uruguayans opposed legalising the sale of marijuana while 24-29\% supported it (Global Commission on Drug Policy 2011). Legalisation of cannabis was tabled in the Parliament of Jamaica in June 2014 and legislation was approved on 22 January 2015 (Associated Press in Kingston 2015).

Box 4 outlines evidence in the cannabis debate.

\section{Diversion of prescribed drugs of misuse}

Dependence on, and diversion of, addictive prescription drugs such as methadone, morphine

BOX 4 Evidence for legalisation of cannabis

The prolonged debate on cannabis legalisation tends to involve abstract concepts such as morality and health $v$. liberty and public safety. The fact that cannabis is easily available in many countries, despite prohibitionist laws, is often ignored and many experts have, controversially, reported that cannabis is no more dangerous than alcohol and tobacco (Advisory Council on the Misuse of Drugs 2008). It is likely that increased cannabis use would lead to increased accidents involving motor vehicles or industrial machinery (Hall 2015). However, although cannabis use would almost certainly increase after legalisation, a large number of minor drug convictions would be avoided and governments would generate considerable tax revenues. This is in contrast to the current situation, in which supplying cannabis provides an income for criminal gangs and other dissident groups.

A recent definitive review of the health effects of regular cannabis use (Hall 2015) reported the following:

- driving while under the influence of cannabis doubles the risk of road accidents (compared with 6-15 times the risk with alcohol): for example, in France cannabis use was estimated to account for $2.5 \%$ of traffic deaths and alcohol for $29 \%$;
- dependence occurs in around $10 \%$ of cannabis users (compared with 32\% for nicotine, 23\% for heroin, $17 \%$ for cocaine, $15 \%$ for alcohol and $11 \%$ for stimulants);

- prolonged heavy cannabis use reduces 10 by 8 points and results in objective changes on magnetic resonance imaging and other neuroimaging investigations;

- cannabis use increases risk of premature ending of education by $17 \%$;

- psychosis and suicide rates are doubled in regular cannabis users, and perhaps $13 \%$ of cases of schizophrenia could be prevented if cannabis were unavailable (this implies that 4700 young men in the UK would have to abstain from cannabis to prevent one case of schizophrenia; there remains controversy over the trend effect the annual incidence of schizophrenia appears to be stable over the past century despite massive increases in cannabis use - but some recent evidence suggests that high-potency cannabis or 'skunk' may have a more significant association with the genesis of schizophrenia);

- cannabis has a modest effect on rates of fatal cardiac events, lung cancer and bronchitis, although these are confounded by tobacco smoking.
These results are based on multiple studies, the most robust of which are two 40-year longitudinal cohort studies in New Zealand. Although the damaging health effects of cannabis are clear, they remain modest, especially compared with the effects of tobacco, alcohol and intravenous drug use.

The gateway hypothesis (that cannabis leads to more damaging drugs such as cocaine) is rather weak - the vast majority of cannabis users do not become dependent and even fewer progress to 'hard' drugs (Sullum 2003). For example, reports from the Canadian Senate's Special Committee on Illegal Drugs (2002) and the UK Advisory Council on the Misuse of Drugs (2008) concluded that only a small proportion of cases of schizophrenia can be ascribed to cannabis use (perhaps $1 \%$, although many people with pre-existing psychotic illness become acutely unwell following misuse of cannabis; Reuter 2007). However, enforcement, arrest and imprisonment have a damaging effect on individuals and their employment prospects. These costs are also transferred to the taxpayer by way of lost income. Cannabis contributes to only a small proportion of acquisitive or violent crime, in contrast to alcohol and cocaine (Reuter 2007). 
and benzodiazepines have become so widespread that dependence on prescription drugs is more common than dependence on illicit drugs. For example, in the UK, the National Treatment Agency for Substance Misuse (2006) estimated that there were around 200000 'problem drug users' (i.e. users of illicit drugs) in the first decade of the 21st century. By contrast, estimates suggest that $2 \%$ of the adult population of the UK (around 1 million people), and also of the USA, have used benzodiazepines regularly for 12 months or over; around half of these for 5-10 years (Ashton 1989, 1994). Similarly, 10-30\% of long-term benzodiazepines users are physically dependent on them (National Institute for Health and Care Excellence 2004). In 1996 more than half of the 360000 people taking benzodiazepines in Australia had been taking them for at least more than 6 months (Australian Bureau of Statistics 1996).

The misuse of prescribed opioid analgesics such as oxycodone has reached epidemic proportions in the USA, with little sign of any reduction (Maxwell 2011; Freynhagen 2013). Weiss et al (2011) reported that $1.7 \%$ of the US population (5.1 million people) had used prescription opioids non-medically in the previous month, with $5 \%$ having done so in the previous year (Fischer 2014). By 2014, misuse of diverted prescription opiates had become the second most common drug of misuse after cannabis. Similarly, in the USA in 2009, the use of a prescription opioid for non-medical reasons was 20 times more common than heroin use and there were more deaths from prescription opioids than from heroin (Weiss 2011). The rise in misuse and mortality from prescription opioids is partly due to aggressive marketing of these drugs for pain, especially chronic non-cancer pain, and difficulty in preventing diversion to the black market (Maxwell 2011; Fischer 2014). Reduced regulation of medical practice, for-profit practice (such as carrying out unnecessary treatments to generate income) and marketing direct to patients may explain why rates of prescription opioid use are around four times higher in the US than in Europe.

Estimates suggest that $4 \%$ of all opioid doses prescribed in the USA are re-sold on the black market (Katz 2010; Dasgupta 2014). The overall cost of prescribed-opioid misuse in the USA in 2007 was estimated to exceed $\$ 56$ million, with 14800 deaths per year (Birnbaum 2011; Fischer 2014). There has been an $8 \%$ increase in patients seeking help for dependency on prescribed analgesics in the UK over the past few years, with 154 deaths from tramadol (compared with 486 for methadone) in 2010-2011 (Ghodse 2011; Stannard 2013).
Wilens et al (2008) reviewed 21 studies (involving over 100000 children and adolescents) assessing the diversion and misuse of stimulants prescribed for attention-deficit hyperactivity disorder (primarily methylphenidate). The studies reported rates of past-year use of diverted prescribed stimulants of 5-9\% in US school-age children and 5-35\% in college students. Between 16 and $29 \%$ of students who were in receipt of a stimulant prescription had at some time been asked to give, sell or trade their medication, and around $25 \%$ of college students had sold on some of their prescribed stimulants.

\section{Legal highs}

It is proving virtually impossible to prevent widespread misuse of a multitude of synthetic 'legal highs'. In 2013, the European Monitoring Centre for Drugs and Drug Addiction (2009) reported that 280 novel psychoactive substances, known as 'legal highs', were available in Europe. One of the best known, mephedrone, was banned in the UK in 2010. Legal highs are newly available, synthetic psychoactive drugs that are not regulated under current legislation (such as the Misuse of Drugs Act 1971 in the UK) in many countries. Legal highs are taken for their temporary stimulant and euphoric effects in a similar way to cannabis, ecstasy or ketamine. Side-effects and overdose often produce symptoms similar to those of illegal stimulants, including serotonin syndrome. In 2001, 5-10\% of young EU citizens admitted to having taken a legal high in the previous year (compared with 25-50\% for cannabis) (Gallup 2011). Legal highs are usually bought on the internet or from dealers in cannabis and ecstasy (Meacher 2013). There are many hundred such chemical compounds, including the cathinone 'meow meow' (the spurious plant food, mephedrone), GBL (gammabutyrolactone, an industrial solvent), BZP (benzylpiperazine) and salvia (an extract from the sage plant). The exact content of the illicit tablets or powders is extremely variable and some supplies may have completely different active agents when purchased at different times.

Legal highs or their chemical precursors are generally produced in bulk in China or India and imported into Europe for packaging or for distribution via the internet (Griffiths 2013). United Nations conventions such as the Convention on Psychotropic Substances are not likely to be enforced, as these countries derive income from this trade (in the same manner that Britain and France regulated the opium trade in China until the Second World War, despite international conventions to the contrary). 


\section{The Psychoactive Substances Act 2016}

The UK's Psychoactive Substances Act came into force on 26 May 2016 (as this article was going to press). It is now an offence in the UK to produce or supply any substance that is 'likely' to be used for its psychoactive effects. This is regardless of risk. Certain substances are excluded: alcohol, nicotine, caffeine and any substance subject to other misuse of drugs regulations. The objective the UK legislation is to close down 'head-shops' and websites that can sell legal highs: simple possession of psychoactive substance is not an offence. Thus, the Act avoids criminalising people who have obtained modest quantities of these drugs for their own use. The legislation indicates that the producer and distributor of the substance must demonstrate that the substance is not 'likely' to be used for its psychoactive effects. Indeed, the producer and distributor will be required to give a credible alternative use for the chemicals they are selling in the event of action against them. Whether the UK legislation can stem the tide of legal highs being sold on the internet and posted to consumers remains to be seen, although this seems highly unlikely given the international nature of internet sales.

\section{Conclusions}

The trade in drugs such as opium and cannabis has persisted since antiquity and flourished under the colonial powers. There seems to have been a brief period of sobriety through the middle of the 20th century due to the interruption of international trade caused by the two World Wars, international prohibition and the advent of totalitarian communist regimes. However, the illicit drug trade expanded and flourished in Western countries after the Second World War. The legalisation of cannabis for recreational use in two US states in 2014 is likely to be a seminal event signalling the end of the current prohibitionist policies against drugs. Similarly, the widespread diversion of prescribed opiates, benzodiazepines and stimulants, along with internet sales of legal highs, means that prohibition by use of criminal laws is now virtually impossible to impose.

\section{References}

Advisory Committee on Drug Dependence (1969) Cannabis. HMSO.

Advisory Council on the Misuse of Drugs (2008) Cannabis: Classification and Public Health. Advisory Council on the Misuse of Drugs.

Ashton $\mathrm{H}$ (1989) Risks of dependence on benzodiazepine drugs: a major problem of long-term treatment. BMJ, 298: 103-4.

Ashton $\mathrm{H}$ (1994) The treatment of benzodiazepine dependence. Addiction, 89: 1535-41.

Associated Press in Kingston (2015) Jamaica decriminalises marijuana. The Guardian, 25 Feb.
Australian Bureau of Statistics (1996) National Health Survey, First Results, Australia, 1995. Australian Bureau of Statistics.

Baumler A (2001) Modern China and Opium: A Reader. University of Michigan Press.

Berridge V (2013) Demons: Our Changing Attitudes to Alcohol, Tobacco and Drugs. Oxford University Press.

Bewley-Taylor DR, Fazey CSJ (2003) The Mechanics and Dynamics of the UN System for International Drug Control. Forward Thinking On Drugs.

Birnbaum HG, White AG, Schiller M, et al (2011) Societal costs of prescription opioid abuse, dependence, and misuse in the United States. Pain Medicine, 12: 657-67.

Booth M (1996) Opium: A History. Simon \& Schuster.

Cappato M, Davies C, Cohn-Bendit DC, et al (2002) Proposal for a Recommendation, 23 December 2002: Recommendation on the reform of the conventions on drugs (B5-0541/2002). European Parliament.

Cabinet Office Strategy Unit (2013) Alcohol Misuse: How Much Does it Cost? Cabinet Office.

Cervantes G (2015) The Cannabis Encyclopedia. Van Patten Publishing.

Chouvy PA (2009) Opium: Uncovering the Politics of the Poppy. I. B. Tauris.

Dasgupta N, Creppage K, Austin A, et al (2014) Observed transition from opioid analgesic deaths toward heroin. Drug and Alcohol Dependence, 145: $238-41$

Davenport-Hines R, Treadwell P (2002) The Pursuit of Oblivion: A Global History of Narcotics. W. W. Norton.

Deitch R (2003) Hemp: American History Revisited: The Plant with a Divided History. Algora.

Drug Policy Alliance (2015) Wasted Tax Dollars. Drug Policy Alliance (http://www.drugpolicy.org/wasted-tax-dollars). Accessed 10 Feb 2016.

European Monitoring Centre for Drugs and Drug Addiction (2009) Annual Report on the State of the Drugs Problem in Europe 2009. EMCDDA.

Farrell M, Buchbinder R, Hall W (2014) Should doctors prescribe cannabinoids? BMJ, 348: 33-6.

Feiling T (2009) The Candy Machine: How Cocaine Took Over the World. Penguin.

Fischer B, Keates A, Bühringer G, et al (2014) Non-medical use of prescription opioids and prescription opioid-related harms: why so markedly higher in North America compared to the rest of the world? Addiction, 109: 177-81.

Freudenberg N (2014) Lethal But Legal: Corporations, Consumption, and Protecting Public Health. Oxford University Press.

Freynhagen R, Geisslinger G, Schug SA (2013) Opioids for chronic noncancer pain. BMJ, 346: $\{2937$.

Gallup Organization (2011) Youth Attitudes on Drugs: Analytical Report (Flash Eurobarometer 330). European Commission.

Ghodse H, Corkery J, Schifano F, et al (2011) Drug-Related Deaths in the UK: Annual Report 2011. International Centre for Drug Policy, St George's, University of London.

Global Commission on Drug Policy (2011) War on Drugs: Report of the Global Commission on Drug Policy. Global Commission on Drugs.

Gootenberg P (ed) (1999) Cocaine: Global Histories. Routledge.

Griffiths P, Evans-Brown M, Sedefov R (2013) Getting up to speed with the public health and regulatory challenges posed by new psychoactive substances in the information age. Addiction, 108: 1700-3.

Hall W (2015) What has research over the past two decades revealed about the adverse health effects of recreational cannabis use? Addiction, 110: $19-35$.

Holden A (2004) Makers and Manners: Politics and Morality in Post-War Britain. Politico.

Karch SB (2005) A Brief History of Cocaine (2nd edn). Taylor and Francis.

Katz MH (2010) Long-term opioid treatment of nonmalignant pain: a believer loses his faith. Archives of Internal Medicine, 170: 1422-4. 
Latimer D, Goldberg J (1981) Flowers in the Blood: The Story of Opium. Franklin Watts.

Lim SS, Vox T, Flaxman AD, et al (2012) A comparative risk assessment of burden of disease and injury attributable to 67 risk factors and risk factor clusters in 21 regions, 1990-2010: a systematic analysis for the Global Burden of Disease Study 2010. Lancet, 380: 2224-60.

LSE Ideas (eds) (2014) Ending the Drugs Wars: Report of the LSE Expert Group on the Economics of Drug Policy. London School of Economics.

Maxwell JC (2011) The prescription drug epidemic in the Unites States: a perfect storm. Drug and Alcohol Reviews, 30: 264-70.

McCoy AW (1972) The Politics of Heroin in Southeast Asia. Harper \& Row McCoy AW (1991) The Politics of Heroin: CIA Complicity in the Global Drug Trade. Lawrence Hill Books.

Meacher MC (2013) Drug policy reform: legal highs. The Psychiatrist, 37: 249-52.

Miron JA (2005) The Budgetary Implications of Marijuana Prohibition. University of Harvard.

Mokdad AH, Marks JS, Stroup DF, et al (2004) Actual causes of death in the United States, 2000. JAMA, 291: 1238-45.

National Institute for Health and Care Excellence (2004) Guidance on the Use of Zaleplon, Zolpidem and Zopiclone for the Short-Term Management of Insomnia Nice [Technology Appraisal Guidance TA77] . NICE.

National Treatment Agency for Substance Misuse (2006) Models of Care for Treatment of Adult Drug Misusers: Update 2006. NTA.

Office of National Drug Control Policy (2013) National Drug Control Strategy: Data Supplement 2013,. Office of National Drug Control Policy (http://www.whitehouse.gov/sites/default/files/ondcp/policy-andresearch/2013 data_supplement_final2.pdf).

Pew Research Centre (2014) America's New Drug Policy Landscape. Pew Research Centre.

Pudney S (2003) The Road to Ruin? Sequences of Initiation into Drug Use and Offending by Young People in Britain (Home Office Research Study 253). Home Office Research, Development and Statistics Directorate.

Quah D, Collins J, Atuesta Becerra LH, et al (2014) Ending the Drug Wars: Report of the LSE Expert Group on the Economics of Drug Policy. LSE Ideas.
Reuter P, Crawford G, Cave J (1988) Sealing the Borders: The Effects of Increased Military Participation in Drug Interdiction. RAND Corporation.

Reuter P, Stevens S (2007) An Analysis of UK Drug Policy: A Monograph Prepared for the UK Drug Policy Commission. UK Drug Policy Commission.

Royal College of Physicians (2001) Alcohol - Can the NHS Afford It? $\mathrm{RCOP}$

Senate Special Committee on Illegal Drugs (2002) Cannabis: Our Position for a Canadian Public Policy. Report of the Senate Special Committee on Illegal Drugs. Senate of Canada.

Stannard C (2013) Opioids in the UK: what's the problem? BMJ, 347: f5108.

Stockwell T, Thomas G (2013) Is Alcohol too Cheap in the UK? The Case for Setting a Minimum Unit Price for Alcohol. Institute of Alcohol Studies.

Sullum J (2003) Marijuana as a 'gateway' drug. Reason, 24 Jan.

United Nations Office on Drugs and Crime (2007) A century of international drug control. Bulletin on Narcotics, LIX (1 and 2): 1-167. Republished 2009. UNODC.

United Nations Office on Drugs and Crime (2009) World Drug Report 2009. UNODC

United Nations Office on Drugs and Crime (2010) World Drug Report 2010. UNODC (http://www.unodc.org/unodc/en/data-and-analysis/ WDR-2010.html).

United Nations Office on Drugs and Crime (2013) Fact Sheet on Statistics and Trends of Illicit Drugs. Appended to World Drug Report 2013 (UN Office on Drugs and Crime). UNODC.

Weiss RD, Potter JS, Fiellin DA, et al (2011) Adjunctive counseling during brief and extended buprenorphine-naloxone treatment for prescription opioid dependence: a 2-phase randomized controlled trial. Archives of General Psychiatry, 68: 1238-46

Wilens TE, Adler LA, Adams J, et al (2008) Misuse and diversion of stimulants prescribed for ADHD: a systematic review of the literature. Journal of the American Academy of Child \& Adolescent Psychiatry, 47 . 21-31.

\section{$\mathrm{MCOs}$}

Select the single best option for each question stem

1 As a cause of death in the world, drug misuse is ranked:

a $1 \mathrm{st}$

b $3 r d$

c 8 th

d 12 th

e 19th

2 International drug prohibition began with the International Opium Convention in:

a 1912

b 1918

c 1939

d 1945

e 1971 .
3 The proportion of US soldiers in the Vietnam War thought to be dependent on opiates was:

a $0.1 \%$

b $1 \%$

c $10 \%$

d $15 \%$

e $50 \%$.

4 The US president who popularised the phrase 'war on drugs' was:

a George Washington

b George W. Bush

c Lyndon Johnson

d J. Edgar Hoover

e Richard Nixon.
5 In the USA in 2009, the use of a prescription opioid for non-medical reasons was how many times more common than heroin use?

a 2 times

b 5 times

c 10 times

d 20 times

e 100 times. 